\title{
Plasma cortisol concentration in Thoroughbred horses during and after standardized exercise tests on a treadmill and effect of conditioning on basal cortisol values
}

\author{
A. Lindner*, Esterina Fazio, Alida M. Ferlazzo., P. Medica and Adriana Ferlazzo
}

* Arbeitsgruppe Pferd, Essen, Germany;

Istituto di Fisiologia Generale e Speciale degli Animali domestici e Chimica Biologica, University of Messina, Messina, Italy

\begin{abstract}
Summary
The behaviour of cortisol concentration in plasma of clinically normal horses performing two different exercise tests on a treadmill was investigated to study the possible value of measuring cortisol for performance diagnosis. In addition, the horses were exercised with different conditioning programmes and their effect on basal plasma cortisol concentration was measured. Finally, the repeatability of the cortisol values measured before and after exercise were examined. Horses were always exercised on a treadmill. The multiple step exercise test consisted of five gallop workouts lasting five minutes' each. The velocity in the first step was $6.0 \mathrm{~m} / \mathrm{s}$. Each consecutive step velocity was increased by $0.5 \mathrm{~m} / \mathrm{s}$. The two-speed exercise test consisted of two runs. In the first run horses were galloped over 1,200 m at a constant velocity of $10,10.5$ or $11 \mathrm{~m} / \mathrm{s}$. Thereafter horses were walked for 30 minutes. The second run over 1,200 m was conducted at speeds of 13, 13.5 or $14 \mathrm{~m} / \mathrm{s}$. Each conditioning programme examined consisted of eleven repetitions of exercise of 5, 15 or 25 minutes' duration at a velocity at which, mathematically, horses had a blood lactate concentration of 2.5 or $4 \mathrm{mmol} / \mathrm{l}$.

During the multiple step test the mean cortisol concentration in plasma showed a tendency to increase $(p=0.07)$. The mean peak of the cortisol concentration in plasma was measured 10 minutes after the test. Thereafter mean cortisol concentration continuously decreased and the day after the test values were similar to those before the test. After the first run of the two-speed test mean plasma cortisol concentration tended to increase $(p=0.08)$, while significant changes were registered after the second run $(p<0.01)$ : It decreased up to the fifth minute after exercise $(p<0.05)$ and increased threreafter reaching a plateau between the 15th and 45th minute after exercise $(p<0.05)$. The morning after the test mean plasma cortisol concentration had returned to the values measured the morning before the test. None of the conditioning programmes had an effect on the mean plasma concentration of cortisol in the horses at rest. The mean coefficient of variation of plasma cortisol concentration in five horses before exercise was $34.1 \%$ and $36.4 \%$ after exercise.

The large individual variability of plasma cortisol concentrations before and after exercise does not allow a good repeatability of results, and enforces the need for multiple blood sampling during exercise. The multiple step exercise test as well as the two-speed exercise test induced increases of the plasma cortisol concentration after exercise. The changes measured supply a basis for studies on treadmills on the value of monitoring the plasma cortisol concentration of sport horses for performance diagnosis.
\end{abstract}

Keywords:

horse, exercise, cortisol, blood plasma, lactate

Konzentration von Plasmakortisol bei Pferden während und nach Laufband-Belastungstests und Einfluß von Training auf den Plasmakortisolgehalt bei Pferden unter Ruhebedingungen

Die Wirkung von zwei verschiedenen Belastungstests auf die Plasmakortisolkonzentration von gesunden Vollblutpferden wurde untersucht, um Referenzwerte für die Leistungsdiagnostik zu bekommen. Außerdem wurde geprüft, ob sechs verschiedene Trainingsprogramme einen Einfluß auf die Plasmakortisolkonzentration von Vollblutpferden haben. Außerdem erfolgte die Berechnung des Variationskoeffizienten für die Messung der Kortisolgehalte im Plasma von Pferden vor und nach Belastung. Alle Belastungen fanden auf einem Laufband statt. Der MehrstufenBelastungstest bestand aus fünf Stufen. Jede Stufe daverte 5 Minuten. In der ersten Stufe liefen die Pferde bei einer Geschwindigkeit von $6 \mathrm{~m} /$ s. Die Geschwindigkeit wurde von Stufe zu Stufe um 0,5 m/s erhöht. Der Zwei-Geschwindigkeiten-Belastungstest bestand aus zwei Läufen über je 1.200 m. Den ersten Lauf absolvierten die Pferde bei einer konstanten Geschwindigkeit von 10, 10,5 oder 11 m/s. Danach wurden die Pferde 30 Minuten lang auf dem Laufband Schritt geführt. Der zweite Lauf erfolgte bei Geschwindigkeiten von 13, 13,5 oder 14 m/s. Jedes untersuchte Trainingsprogramm bestand aus 11 gleichen Belastungen, die in einem Zeitraum von 3 Wochen von den Pferden gelaufen wurden. Die Belastungen daverten 5, 15 oder 25 Minuten. Die Laufgeschwindigkeit entsprach der Geschwindigkeit, die in einem Mehrstufen-Belastungstest vor dem jeweiligen Trainingsprogramm bei den Pferden eine Laktatkonzentration im Blut von 2,5 oder $4 \mathrm{mmol} / \mathrm{I}$ hervorgerufen hatte.

Während des Mehrstufentests nahm die mittlere Plasmakortisolkonzentration tendentiell zu ( $p=0,07)$. Der höchste mittlere Kortisolgehalt im Plasma wurde 10 Minuten nach dem Test gemessen. Danach fiel die Konzentration kontinuierlich ab und war am Tag danach auf dem gleichen Niveau wie vor dem Test. Nach dem ersten Lauf des Zwei-Geschwindigkeitentests nahm die mittlere Kortisolkonzentration im Plasma tendentiell zu $(p=0,08)$, nach dem zweiten Lauf sogar signifikant $(p<0,01)$. Allerdings fiel der mittlere Kortisolgehalt im Plasma bis zur fünften Minute nach Belastung zuerst ab $(p<0,05)$, stieg danach an und bildete ein Plateau zwischen der 15ten und 45ten Minute nach Belastung $(p<0,05)$. Am Morgen nach dem Belastungstest waren die mittleren Kortisolgehalte wieder auf dem Stand von vor dem Test. Keines der angewendeten Trainingsprogramme zeigte Wirkung auf die mittlere Kortisolkonzentration der Pferde unter Ruhebedingungen. Der mittlere Variationskoeffizient der Plasmakortisolkonzentration vor und nach Belastung betrug 34, 1\% und 36,4\%.

Der festgestellte Variationskoeffizient ist hoch. Dies bedeutet eine schlechte Wiederholbarkeit für die Kortisolmessungen und betont die Bedeutung der mehrfachen Blutentnahme bei Belastung. Die Veränderungen der Kortisolkonzentration im Blut bei den Belastungstests dienen als Referenz für weitere Studien, um den Nutzen der Messung dieser Variablen für die Leistungsdiagnostik zu prüfen.

Schlüsselwörter: Pferd, Belastung, Kortisol, Blutplasma, Laktat 


\section{Introduction}

Standardized exercise tests are used for performance diagnosis of horses (Persson 1983). Variables normally determined in this tests are blood lactate concentration, heart rate and maximal oxygen consumption capacity. Other biochemical variables like cortisol could be measured too to possibly provide additional information on performance capacity.

Physical stress influences the cortisol response of the horse (Thornton 1985). Glucocorticoids are anti-inflammatory, increase glycogen deposition, stimulate lipolysis and enhance hepatic gluconeogenesis (Keele et al. 1982). The significance for performance diagnosis of the changes in cortisol concentration with horses during and after exercise is not clear. Literature data is controversial. Garcia and Beech (1986) and Church et al. (1987) did not find training-induced changes of plasma cortisol after exercise, while Müller et al. (1990), Freestone et al. (1991) found smaller increases and a faster return to base levels after exercise following training and Grosskopf et al. (1983) observed a similar pattern of cortisol concentration in horses with a better performance after endurance competition compared to pre-training levels and to horses with lower performance. Wilson et al. (1991) reported on a decrease of baseline cortisol concentration in thoroughbred horses in the initial stage of the training for racing and that horses fit for racing had lower baseline cortisol concentration than when in early race training. But, Persson et al. (1980) found that standardbred horses with poor performance had also lower basal cortisol concentration and the increase of cortisol after ACTH application was smaller than in horses performing at an expected level, and Baker et al. (1982) could not find differences in the cortisol concentration in plasma between resting thoroughbred horses performing at the expected level and not performing well. Finally, Golland et al. (1996) demonstrated that standardbred horses with clinical signs of experimentally induced overtraining had a lower increase of cortisol in plasma in response to exercise as compared with values before overtraining and with a control group. They also reported that basal plasma cortisol concentration and the via ACTH injection induced plasma cortisol reaction were not different between overtrained and control horses.

The behaviour of cortisol concentration in plasma of clinically normal horses performing two different exercise tests on a treadmill was investigated to study the possible value of measuring cortisol for performance diagnosis. In addition, the horses were exercised with different conditioning programmes and their effect on basal plasma cortisol concentration was measured. Finally, the repeatability of the cortisol values measured before and after exercise was examined.

\section{Materials and methods}

Horses

Five conditioned thoroughbred horses $3.4 \pm 0.5$ (SD) years old, weighing $467 \pm 29$ (SD) $\mathrm{kg}$ trained for a period of two months to run on a motorized treadmill ( $6 \%$ incline) at speeds up to $14 \mathrm{~m} /$ $\mathrm{s}$ were used for the studies. Horses were kept in $3 \times 3 \mathrm{~m}$ boxes at night, at day they were turned out on pasture. They were fed a concentrate of $4.5 \mathrm{~kg}$ daily (Reform-Mix; Hoeveler Spezialfutterwerke, Germany), and $5 \mathrm{~kg}$ of silage (in a relation of 2:1 grass to cornsilage). Hay, straw and water were always available. All the exercise tests and workouts were performed on a high-speed treadmill (Mustang ${ }^{\circledR}$, Kagra AG, Fahrwangen, Switzerland) with horses wearing a heart rate meter (Polar Electro OY, Finland). The horses were always warmed up following the same routine: 5 minutes walk at $1.6 \mathrm{~m} / \mathrm{s}$ and 5 minutes trot at $3.4 \mathrm{~m} / \mathrm{s}$ without incline. After exercise they walked during the whole blood sampling period at $1.6 \mathrm{~m} / \mathrm{s}$ without incline.

\section{Design of studies}

Study to determine the effect of standardized exercise tests Horses were submitted to two different test protocols: a twospeed exercise test and a multiple step exercise test. During and after the multiple step test blood samples for measuring cortisol were collected at 7:00 a.m., before exercise but after warm up, within 10 seconds after each step and in the 5th, 10 th, 15th, 30th, 45th and 60th minute, and at 7:00 a.m. on the morning after the test.

To examine the effects of the two-speed exercise test blood samples for measuring cortisol were collected at 7:00 a.m., before exercise but after warm up, in the $1 \mathrm{st}, 5$ th, 10 th and 15 th minute after both runs and in the 30th, 45th and 60th minute and at 7:00 a.m. on the morning after the second run of each test. Blood samples for lactate determination were taken in the 1st, $3 r d, 5$ th minute after both runs of a test and additionally in the 7th, 10th and 12th minute after the second run of each test.

\section{Study to determine effect of conditioning programmes}

In a randomized $5 \times 6$ latin square cross over study design (five horses $x 6$ conditioning programmes), horses were exercised at $v_{2.5}$ or $v_{4}$ during 5,15 or 25 minutes for 11 times with a one day rest between two consecutive workouts $v_{2.5}$ or $v_{4}$ : velocity at which, mathematically, a lactate concentration of 2.5 or 4 $\mathrm{mmol} / \mathrm{l}$ blood is determined, when it is run under defined conditions). Before each conditioning programme horses performed a standardized exercise test to determine their individual $v_{2.5}$ and $v_{4}$. To examine the effect of the conditioning programme on cortisol concentration in plasma, blood samples were always taken from the horses at 7:00 a.m., before and after each conditioning programme. Horses had about one week without standardized exercise between conditioning programmes. During this period horses were walked and trotted on the treadmill every second day.

Study to determine coefficient of variation of cortisol Blood was taken from five of the horses before exercise at 7:00 a.m. and within 10 seconds after the end of exercise. This was repeated four times for each horse on days 1, 7, 13 and 19 of a single conditioning programme. Duration and intensity of the exercise were the same for a single horse, but differed between horses (Table 1). The duration of exercise was 5, 15 or 25 minu- 
tes, and horses were run at $v_{2.5}$ or $v_{4}$. The $v_{2.5}$ and $v_{4}$ of each horse was determined with a standardized multiple step exercise test two days before the beginning of the conditioning period. ned from the individual blood lactate concentration-running speed relationship by exponential regression equation (Galloux 1991).

Tab. 1: Duration and velocity run $\left(v_{25}\right.$ or $\left.v_{4}\right)$ by horses on a treadmill during four exercise sessions/horse and mean ( \pm SD) heart rate during, blood lactate concentration after exercise and plasma cortisol concentration before and after exercise

Daver und Geschwindigkeit von Pferden, ihre mittlere Herzfrequenz während, Blutlaktatkonzentration nach und Plasmakortisolkonzentration vor sowie nach Belastung auf einem Laufband (je Pferd 4 Belastungen; Mittelwert \pm Standardabweichung

\begin{tabular}{|c|c|c|c|c|c|c|c|}
\hline \multirow[t]{2}{*}{ Horse } & \multicolumn{3}{|c|}{ Exercise } & \multirow{2}{*}{$\begin{array}{l}\text { Heart rate } \\
\text { (beats/min) }\end{array}$} & \multirow{2}{*}{$\begin{array}{c}\text { Blood } \\
\text { lactate } \\
\text { (mmol/l) }\end{array}$} & \multicolumn{2}{|c|}{ Cortisol (nmol/l) } \\
\hline & $\begin{array}{l}\text { Duration } \\
\text { (minutes) }\end{array}$ & $\mathrm{v}_{2.5}(\mathrm{~m} / \mathrm{s})$ & $\mathrm{v}_{4}(\mathrm{~m} / \mathrm{s})$ & & & 7:00 a.m. & $\begin{array}{c}\text { After } \\
\text { exercise }\end{array}$ \\
\hline 1 & 5 & 7.5 & - & $160 \pm 10$ & $2.74 \pm 0.59$ & $248 \pm 89$ & $326 \pm 94$ \\
\hline 2 & 5 & - & 6.9 & $154 \pm 14$ & $5.34 \pm 1.40$ & $306 \pm 72$ & $390 \pm 86$ \\
\hline 3 & 25 & - & 7.6 & $164 \pm 3$ & $3.14 \pm 0.53$ & $271 \pm 74$ & $427 \pm 181$ \\
\hline 4 & 15 & 7.4 & - & $173 \pm 9$ & $3.55 \pm 0.27$ & $287 \pm 78$ & $441 \pm 138$ \\
\hline 6 & 15 & - & 8.6 & $177 \pm 1$ & $2.56 \pm 0.43$ & $433 \pm 245$ & $640 \pm 171$ \\
\hline
\end{tabular}

Standardized exercise tests

\section{Multiple step exercise test}

It consisted of five gallop workouts of five minutes' duration each. Between two consecutive steps there was a resting period of $60 \mathrm{~s}$. The velocity in the first step was $6.0 \mathrm{~m} / \mathrm{s}$. Each consecutive step was increased by $0.5 \mathrm{~m} / \mathrm{s} . v_{2.5}$ and $v_{4}$ were determi-
Two-speed exercise test

This test consisted of two runs. In the first run horses were galloped over 1,200 $\mathrm{m}$ at a constant velocity of 10, 10.5 or $11 \mathrm{~m} / \mathrm{s}$. Thereafter horses were walked for 30 minutes. The second run over 1,200 $\mathrm{m}$ was conducted at speeds of 13, 13.5 or $14 \mathrm{~m} / \mathrm{s}$ (Table 2). The speed at which horses ran depended on their $v_{4}$ values determined with the multiple step

Tab. 2: Running speed of horses in the 1 st and 2 nd run over 1,200 $\mathrm{m}$ of the two-speed exercise test on a treadmill, maximal blood lactate concentration after each run and mean heart rate during exercise

Geschwindigkeit von Pferden im 1. und 2. Lauf eines Zweigeschwindigkeiten-Tests über 1.200 m, ihre maximale Blutlaktatkonzentration nach sowie mittlere Herzfrquenz während jedes Laufs

\begin{tabular}{|c|c|c|c|c|c|c|}
\hline Horse & \multicolumn{3}{|c|}{ 1st run } & \multicolumn{3}{c|}{ 2nd run } \\
\hline & $\begin{array}{c}\text { Velocity } \\
(\mathrm{m} / \mathrm{s})\end{array}$ & $\begin{array}{c}\text { Maximal blood } \\
\text { lactate } \\
(\mathrm{mmol} / \mathrm{l})\end{array}$ & $\begin{array}{c}\text { Mean heart rate } \\
\text { (beats/minute) }\end{array}$ & Velocity (m/s) & $\begin{array}{c}\text { Maximal } \\
\text { blood lactate } \\
\text { (mmol/l) }\end{array}$ & $\begin{array}{c}\text { Mean heart rate } \\
\text { (beats/minute) }\end{array}$ \\
\hline 1 & 11.0 & 3.80 & 189 & 14.0 & 12.85 & 203 \\
\hline 2 & 11.0 & 6.15 & 195 & 14.0 & 14.25 & 204 \\
\hline 3 & 10.0 & 4.25 & 195 & 13.0 & 13.80 & 204 \\
\hline 4 & 10.0 & 5.75 & 190 & 13.0 & 17.35 & 192 \\
\hline 5 & 10.5 & 3.95 & 203 & 13.5 & 11.15 & 213 \\
\hline 6 & 10.0 & 8.30 & 207 & 13.0 & 20.05 & 209 \\
\hline 7 & 10.5 & 4.75 & 207 & 13.5 & 13.55 & 214 \\
\hline
\end{tabular}


test. Horses with lower $v_{4}$ values galloped at $10 \mathrm{~m} / \mathrm{s}$ in the first run and at $13 \mathrm{~m} / \mathrm{s}$ in the second run, and horses with the higher $v_{4}$ values galloped at $11 \mathrm{~m} / \mathrm{s}$ in the first and $14 \mathrm{~m} / \mathrm{s}$ in the second run.

\section{Blood sample handling}

For the cortisol and lactate measurement blood was collected from a jugular vein into evacuated $\mathrm{Na}$-heparinate containing tubes. Within 30 minutes samples were centrifuged at 6,000 g for 10 minutes, and the plasma was transferred to plastic vials and kept stored at $-20^{\circ} \mathrm{C}$ until analysis, which was normally done within two months.

For the lactate determination $20 \mu$ l of blood were transferred as soon as possible after collection into vials with $200 \mu$ icecold $0.6 \mathrm{n}$ perchloric acid. Samples were centrifuged for $5 \mathrm{mi}$ nutes by $12,000^{9}$ and the supernatant was transferred to empty vials and stored at $4{ }^{\circ} \mathrm{C}$ until analysis, normally within two days.

\section{Analysis}

\section{Cortisol}

Plasma concentration of cortisol was analyzed in duplicate with an immunoenzymatic assay (Boehringer Mannheim Immunodiagnostics no. 649945). The coefficient of variation between days was $8 \%$.

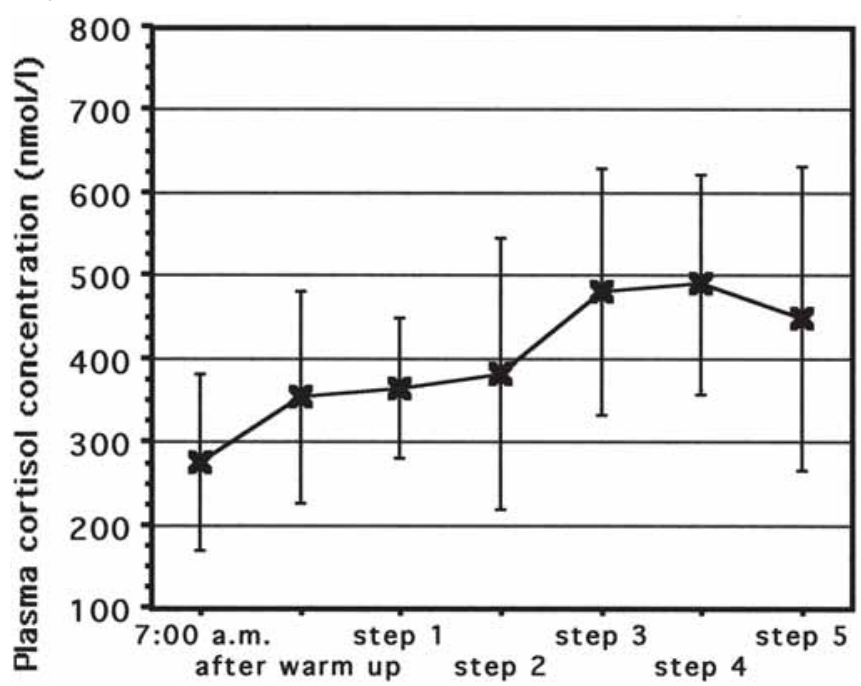

Fig. 1: Cortisol in plasma of horses before and during multiple step exercise test (mean \pm standard deviation; $\mathrm{n}=5$ )

Kortisol im Plasma von Pferden vor und während eines MehrstufenBelastungstests (Mittelwert \pm Standardabweichung; $n=5$ )

\section{Lactate}

The blood lactate analysis was done with an EPOS 5060 analyzer (Eppendorf-Netheler-Hinz) using an enzymatic test kit (Behring, OSUA 40). The coefficient of variation for this enzymatic method from day to day was $7.5 \%$ at a lactate concentration of $2.15 \mathrm{mmol} / \mathrm{l}$ (Precipath ${ }^{\circledR} \mathrm{S}$ Boehringer Mannheim, Nr. 125202) and $3.7 \%$ at $4.4 \mathrm{mmol} / \mathrm{I}$ (SIGMA lactate, $\mathrm{Nr}$. 82610).

\section{Statistics}

Data shown are means of duplicate analyses for each sample. Data are presented as mean \pm standard deviation. The coefficient of variation of the variables before and after exercise was calculated dividing the standard deviation through the mean and multiplying by 100 .

To determine whether an exercise test had an effect an analysis of variance for repeated measures was applied. Effects of conditioning programmes on variables were examined with analysis of variance for repeated measures. If significant effects were found, Fishers' test was used post-hoc. $p<0.05$ was used as a level to denote significant differences.

\section{Results}

During the multiple step test there was a tendency for the cortisol concentration in plasma to increase ( $p=0.07$; Figure 1). The peak cortisol concentration in plasma was measured 10 minutes after the test (Figure 2). Thereafter the cortisol concentration decreased continuously $(p<0.01)$. On the morning after the test the mean cortisol concentration was back to the values measured on the morning before the test (Figure 2).

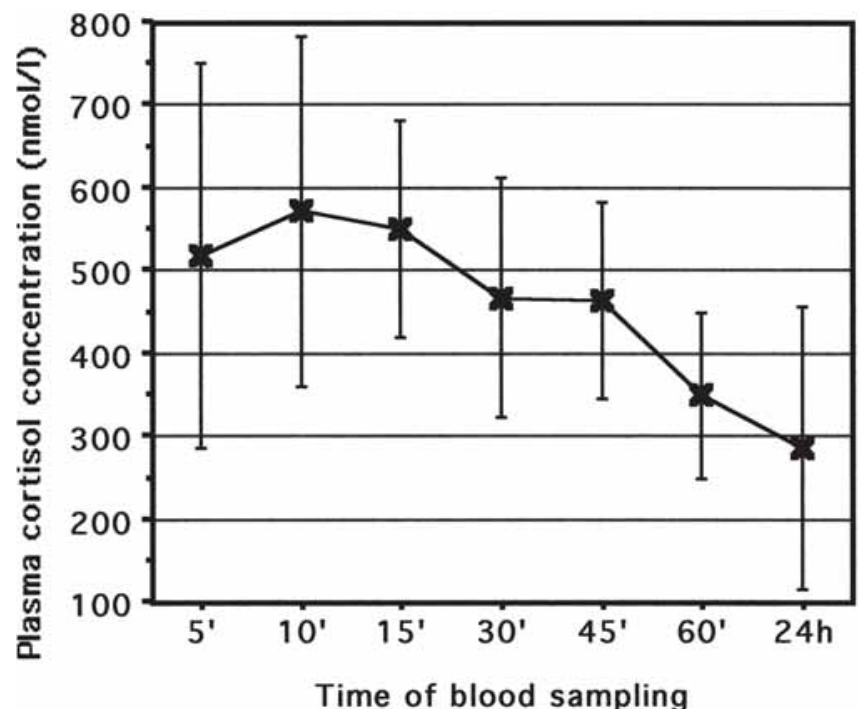

Fig. 2: Cortisol in plasma of horses after multiple step exercise test (mean \pm standard deviation; $\mathrm{n}=5$ )

Kortisol im Plasma von Pferden nach einem Mehrstufen-Belastungstest (Mittelwert \pm Standardabweichung; $n=5$ )

After the first run of the two-speed test plasma cortisol concentration tended to increase $(p=0.08)$. After the second run the mean plasma cortisol concentration changed significantly ( $p$ $<0.01$ ). Initially it decreased in the 5th minute after the run and thereafter it increased reaching a plateau between the 15th and 45 th minute after the run $(p<0.05$ respectively compared with values measured before the 2 nd run). The mean cortisol concentration in plasma measured at 7:00 a.m. on the morning after the test was not different from the value measured at 7:00 a.m. on the testing day (Figure 3).

None of the conditioning programmes had an effect on the plasma concentration of cortisol at 7:00 a.m. (Table 3). 
The coefficient of variation of cortisol before exercise of single horses ranged from $24 \%$ to $57 \%$. After exercise the values were between $22 \%$ and $60 \%$. After exercise, in all horses plasma cortisol concentration was higher as compared with values before exercise taken at 7:00 a.m. (Table 1).

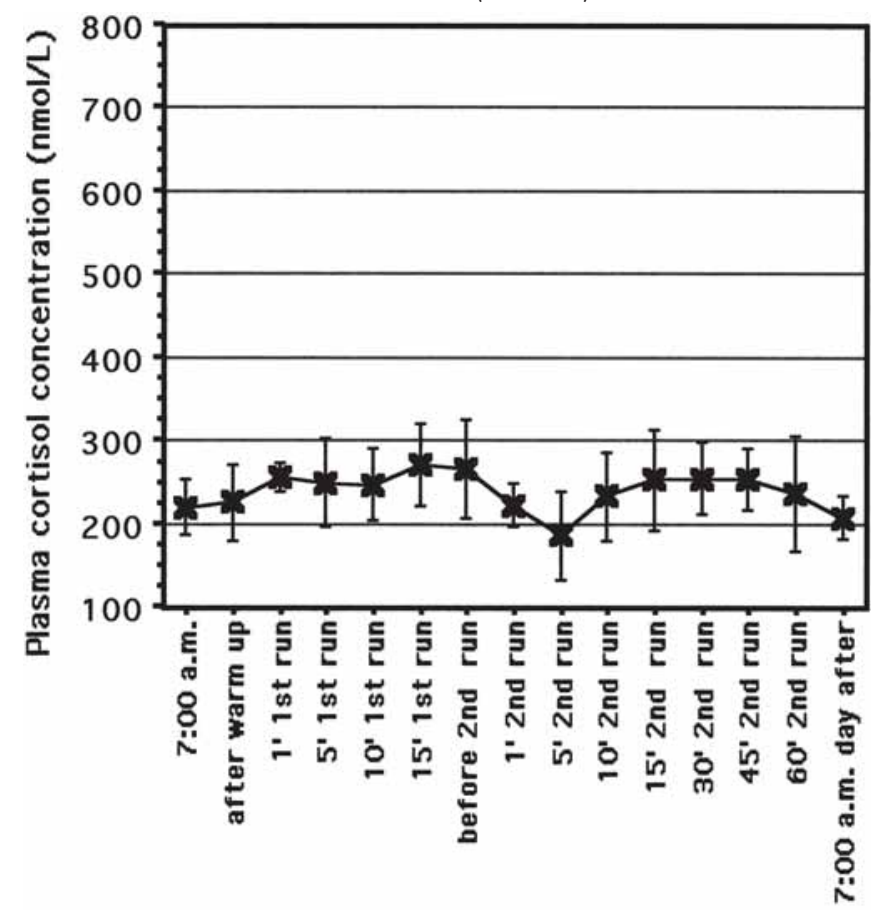

Time of blood sampling

Fig. 3: Cortisol in plasma of horses before and after the $1 \mathrm{st}$ and $2 \mathrm{nd}$ run of a two-speed exercise test (mean \pm standard deviation; $n=5$ )

Kortisol im Plasma von Pferden vor und nach dem ersten und zweiten Lauf eines Zweigeschwindigkeiten-Belastungstests (Mittelwert \pm Standardabweichung; $n=5$ )

\section{Discussion and conclusions}

The two-speed and especially the multiple-step exercise tests are used routinely under field conditions by our group to estimate endurance of sport horses by calculating their $v_{4}$ from the blood lactate-running speed relation established with the tests $\left(v_{4}=\right.$ velocity run under defined conditions at which, mathematically, a blood lactate concentration of $4 \mathrm{mmol} / \mathrm{l}$ is determined; von Wittke et al. 1994; Werkmann et al. 1996; Guhl et al. $1996 a+b$; Lindner 1998). It has been shown that these two types of exercise tests increase plasma cortisol concentration in thoroughbred and standardbred horses when run on a track (Lindner 1992; Lindner et al. 2000). Both types of exercise tests induced increases of the plasma cortisol concentration after exercise on the treadmill too. However, changes produced by the two-speed test were smaller than those by the multiple-step test. The different magnitude of reaction of the cortisol concentration in plasma of horses seems to indicate that duration of exercise induces a larger increase than speed of exercise. But, this assumption may be valid for treadmill conditions only, because speed of the second run of the two-speed test and therefore exercise stress may not increase sufficiently to examine a horse with high endurance. It has been stated that measurable increases of plasma or serum cortisol concentration in horses after exercise only occur if exercise load is sufficiently stressful (Thornton 1985). In man this depends on the fitness of an athlete (Kiær 1996), and it may also hold for horses (Snow and McKenzie 1977; Müller et al. 1990; Freestone et al. 1991). From the results of the few studies available with sufficient sampling times after exercise it can be deduced that the peak cortisol concentration will normalize within the first 60 minutes af-ter exercise (FlisinskaBojanowska et al. 1974; Colborn et al. 1991). This is substantiated by the results of this study.

A singular behaviour of the plasma cortisol concentration was observed after the 2 nd run of the two-speed exercise test: first there was a pronounced decline of the mean plasma cortisol concentration in the 5th minute and thereafter only, the mean cortisol concentration increased and showed a plateau between the 15th and 45th minute after exercise. The plasma cortisol concentration of four out of five horses reacted this way, and in the other horse the drop was protracted by five minutes followed by an increase as well. Between the 1 st and the $2 \mathrm{nd}$ run of the test 30 minutes of time elapsed. It may be that the cortisol secretion after an exercise stimulus is delayed within a certain amount of time if another exercise stimulated the cortisol secretion be-fore. This behaviour certainly documents the importance of consecutive blood sampling in short intervals after exercise.

Tab. 3: Cortisol concentration in plasma (nmol/l) of horses at 7:00 a.m. before and after different conditioning programmes $(\mathrm{n}=5 ;$ mean \pm standard deviation)

Plasmakortisolgehalt (nmol/l) von Pferden um 7:00 Uhr, vor und nach verschiedenen Trainingsprogrammen ( $n=5$; Mittelwert \pm Standardabweichung

\begin{tabular}{|c|c|c|c|c|c|c|}
\hline \multirow{2}{*}{$\begin{array}{c}\text { Time of blood } \\
\text { sampling }\end{array}$} & \multicolumn{7}{|c|}{ Conditioning programme } \\
\cline { 2 - 7 } & 5 minutes & $\begin{array}{c}\mathrm{v}_{2.5} \\
15 \text { minutes }\end{array}$ & $\begin{array}{c}\mathrm{v}_{2.5} \\
25 \text { minutes }\end{array}$ & $\begin{array}{c}\mathrm{v}_{4} \\
5 \text { minutes }\end{array}$ & $\begin{array}{c}\mathrm{v}_{4} \\
15 \text { minutes }\end{array}$ & $\begin{array}{c}\mathrm{v}_{4} \\
25 \text { minutes }\end{array}$ \\
\hline before & $280 \pm 80$ & $295 \pm 72$ & $296 \pm 89$ & $297 \pm 94$ & $257 \pm 89$ & $242 \pm 52$ \\
\hline after & $219 \pm 69$ & $265 \pm 92$ & $304 \pm 112$ & $262 \pm 63$ & $251 \pm 80$ & $219 \pm 51$ \\
\hline
\end{tabular}


There was no measurable effect of the examined conditioning programmes on mean plasma cortisol levels in resting horses (7:00 a.m. samples). It may be that exercise workload of the conditioning programmes applied was not large enough for the thoroughly prepared horses to induce adaptations which would have been reflected in the cortisol concentration in plasma. This is the most reasonable explanation for the result because none of the other physiological and biochemical variables measured in these horses demonstrated an effect of the conditioning programmes (Ferlazzo et al. 1996; Werkmann et al. 1996). Only the blood lactate concentration after exercise at $\mathrm{v}_{4}$ during 25 minutes' duration decreased during the conditioning period (Werkmann et al. 1996). It is also poss-ible, that the cortisol concentration in plasma of resting horses does not allow their performance capacity to be determined, and an adaptation would only have been demonstrable evaluating the response to standardized exercise. Another approach could have been to measure the response to the application of ACTH (James et al. 1970; Rossdale et al. 1982; Linden et al. 1991a; Golland et al. 1996). However, this method may not be readily applicable to sound sport horses, and may be more appropriate for the diagnosis in horses not performing at the expected level.

The rather high variability of the plasma cortisol concentration within a horse before and after exercise observed in this study may also account for the lack of significant effects. Lindner et al. (1990) calculated a coefficient of variation for plasma cortisol concentration in five horses during five consecutive days between $21 \%$ and $64 \%$, and Baker et al. (1982) reported on the coefficient of variation of one horse between days being $20 \%$. The reason for this variability is most likely that the plasma cortisol concentration in horses exhibits an ultradian rhythm superimposed upon the circadian rhythm, and that the individual rhythms are variable within the same horse (Evans et al. 1977). Reproducibility of plasma cortisol measurements in experiments can be expected to be poor, and the value of measuring a single cortisol concentration for performance diagnosis questionable. This is the opinion of many authors (Evans et al. 1977; Thornton 1985; Wilson et al. 1991). However, in most studies only one blood sample is taken in resting horses (Baker et al. 1982; Lindner et al. 1990), and after exercise (James et al. 1970; Grosskopf et al. 1983; Snow et al. 1983; Linden et al. 1991 a; Desmecht et al. 1996), or more than 15 minutes are within two blood samples (Rossdale et al. 1982; Garcia and Beech 1986; Church et al. 1987; Freestone et al. 1991).

In conclusion, the large individual variability of plasma cortisol concentrations before and after exercise does not allow a good repeatability of results. Exercising conditioned horses repeatedly for up to 25 minutes' duration at $v_{25}$ and $v_{4}$ during a period of three weeks does not affect plasma cortisol concentrations sampled in horses at 7:00 a.m.. The multiple step exercise test as well as the two-speed exercise test induced increases of the plasma cortisol concentration after exercise. The range of changes measured may supply a basis for future studies on treadmills on the value of monitoring the plasma cortisol concentration of sport horses for performance diagnosis.

\section{Acknowledgements}

We are very grateful to the Verein zur Förderung der Forschung im Pferdesport, Wissenschaftliche Gesellschaft der Schwarzwald-Tierklinik, Höveler Spezialfutterwerke and Horst Dieter Beyer for the material and financial support, to Dr. Bidlingmaier of the Institut für Klinische Biochemie of the University of Bonn for allowing us to run all the lactate analysis in his laboratory.

This work was supported by a grant (60\%) from MURST, Italy.

\section{References}

Baker, H.W.G., I.D.C. Baker, V.M. Epstein and B. Hudson (1982): Effect of stress on steroid hormone levels in racehorses. Australian Vet. J. 58, 70-71

Colborn, D.R., D.L. Thompson, T.L. Roth, J.S. Capehart and K.L. White (1991): Responses of cortisol and prolactin to sexual excitement and stress in stallions and geldings. J. Anim. Sci. 69, 2556-2562

Church, D.B., D.L. Evans, D.R. Lewis and R.J. Rose (1987): The effect of exercise on plasma adrenocorticotrophin, cortisol and insulin in the horse and adaptations with training. In: Equine Exercise Physiology 2. ICEEP Publications, Davis (Gillespie, J.R., Robinson, N.E. (eds.), 506-515

Desmecht, D., A. Linden, H. Amory, T. Art and P. Lekeux (1996): Relationship of plasma lactate production to cortisol release following completion of different types of sporting events in horses. Vet. Res. Commun. 20, 371-379

Evans, J.W., C.M. Winger and E.J. Pollak (1977): Rhythmic cortisol secretion in the equine: analysis and physiological mechanisms. J. Interdiscipl. Cycle res. 8, 111-121

Ferlazzo, A., E. Fazio, P. Medica and A. Lindner (1996): Coefficient of variation of and effect of conditioning on concentration of plasma total and free iodothyronines in Thoroughbred horses. Pferdeheilkde. $12,493-495$

Flisinska-Bojanowska, A., K. Skwarlo, J. Lukaszewska, D. Bobilewicz, M. Wilk and J. Gill (1974): Diurnal variations of serum cortisol and $\mathrm{PBI}$ in the thoroughbred horse and effect of physical effort on plasma cortisol concentration. Bulletin de l'Academie Polonaise des Sciences, 22, 719-723

Freestone, J.F., K.J. Wolfsheimer, S.G. Kamerling, G. Church, J. Hanra and C. Bagwell (1991): Exercise induced hormonal and metabolic changes in thoroughbred horses: effects of conditioning and acepromazine. Equine vet. J. 23, 219-223

Galloux, P. (1991): Contribution à I'élaboration d'une planification de la préparation énergétique du cheval de concours complet. Thèse de doctorate, Faculte des Sciences de l'Université de Poitiers, France

Garcia, M.C. and J. Beech (1986): Endocrinologic, hematologic and heart rate changes in swimming horses. Am. J. Vet. Res. 47, 2004 2006

Golland, L.C., D.L. Evans, G.M. Stone, C.M. Tyler, R.J. Rose and D.R. Hodgson (1996): The effect of overtraining on plasma cortisol concentrations at rest and in response to exercise and administration of synthetic adrenocorticotropin in standardbred racehorses. Pferdeheilkde. 12, 531-533

Grosskopf, J.F.W., J.J. van Rensburg and H.J. Bertschinger (1983): Hematology and blood biochemistry of horses during a $210 \mathrm{~km}$ endurance ride. In: Equine Exercise Physiology 1. Granta Editions, Cambridge (Snow, D.H., Persson, S.G.B., Rose, R.J. (eds.), $416-424$

Guhl, A., A. Lindner and P. von Wittke (1996 a): Reproducibility of the blood lactate-running speed curve in horses under field conditions. Amer. J. Vet. Res. 57, 1059-1062

Guhl, A., A. Lindner and P. von Wittke (1996 b): Use of the relationship between blood lactate and running speed to determine the exercise intensity of horses. Vet. Record 139, 108-1 10

James, V.T.H., M.W. Horner, M.S. Moss and A.E. Rippon (1970): Adrenocortical function in the horse. J. Endocr. 48, 319-335 
Keele, C.A., E. Neil and J. Joels (1982): Samson Wright's Applied Physiology, 13th Ed., Oxford University Press, Oxford, 532-533

Kiær, M. (1996): Hormonelle und metabolische Regulation während körperlicher Arbeit und in der Regenerationsphase nach Trainingsund Wetkampfbelastungen. Dtsch. Zts. Sportmedizin, 47, Sonderheft, $211-215$

Linden, A., T. Art, H. Amory, D. Desmecht and P. Lekeux (1991 a): Comparison of the adrenocortical response to both pharmacological and physiological stresses in sport horses. J. Vet. Med. A 37, 601-604

Linden, A., T. Art, H. Amory, A.M. Massart, C. Burvenich and P. Lekeux (1991 b): Quantitative buffy coat analysis related to adrenocortical function in horses during a three day event competition. J. Vet. Med. A 38, 376-382

Lindner, A. (1992): Plasma cortisol changes in thoroughbred horses after standardized exercise tests. Proceedings Vth Congress International Society of Animal Clinical Biochemistry, Parma, Italy: 327-332

Lindner, A. (1998): $v_{4}$ allows to distinguish better the performance level of Standardbred horses than $v_{200}$. Proc. Conf. Equine Sports Med. Sci.. Lindner, A. (ed.), Wageningen Pers, Wageningen, 251-253

Lindner, A., Y. Will and J. Chrispeels (1990): Referenzwerte für Cortisol, T. und T-Uptake bei verschiedenen Pferdegruppen bestimmt mittels Fluoreszenz-Polarisations-Immunoassays (FPIAs). Berl. Münch. Tierärztl. Wschr. 103, 411-416

Lindner, A., E. Fazio and A. Ferlazzo (2000): Effect of age and performance parameters on plasma cortisol concentration in Standardbred racehorses during exercise. Pferdeheilkde. Submitted

Müller, C., M. Nagel, K. Kühl und E. Kalm (1990): Möglichkeiten der Leistungsbeurteilung beim Pferd anhand physiologischer Parameter während der Eigenleistungsprüfung. In: KTBL-Schrift 344, Landwirtschaftsverlag GmbH, Münster-Hiltrup, 174-183

Persson, S.G.B. (1983): Evaluation of exercise tolerance and fitness in the performance horse. In: Equine Exercise Physiology 1. Cambridge: Granta Editions (Snow, D.H., Persson, S.G.B., Rose, R.J., eds.), 441-457

Persson, S.G.B., M. Larsson and A. Lindholm (1980): Effects of training on adreno-cortical function and red-cell volume in Trotters. J. Vet. Med. A 27, 261-268
Rossdale, P.D., P.N. Burguez and R.S.G. Cash (1982): Changes in blood neutrophil/lymphocyte ratio related to adrenocortical function in the horse. Equinevet. J. 14, 293-298

Snow, D.H. and G. McKenzie (1977): Some metabolic effects of maximal exercise in the horse and adaptations with training. Equine vet. J. 9, 134-140

Snow, D.H., D.K. Mason, S.W. Ricketts and T.A. Douglas (1983): Post race blood biochemistry in Thoroughbreds. In: Equine Exercise Physiology 1. Cambridge: Granta Editions (Snow D.H., Persson S.G.B., Rose R.J., eds.), 389-399

Thornton, J.R. (1985): Hormonal responses to Exercise and training. Vet. Clinics of North America, Eq. Practice 1, 477-496

Werkmann, J., A. Lindner and H.H.L. Sasse (1996): Conditioning effects in horses of exercise of 5, 15 or 25 minutes' duration at two blood lactate concentrations. Pferdeheilkde. 12, 474-479

Wilson, W.D., S. Kingery and D.H. Snow (1991): The effect of training on adrenocortical function in thoroughbred racehorses. Equine Exercise Physiology 3, ICEEP Publications, Davis CA (Persson, S.G.B., Lindholm, A., Jeffcott, L.B. eds.), 482-489

Wittke von, P., A. Lindner, E. Deegen and H. Sommer (1994): Effects of training on blood lactate-running speed relationship in the thoroughbred racehorse. J. Appl. Physiol. 77, 298-302

\section{Dr. Arno Lindner}

Laurahöhe 14

45289 Essen

Tel.: (02 01) 5718873

Fax: (02 01) 5718874

www.agpferd.de 